\title{
DESIGN AND FABRICATION OF NON DUST PAPER WOOD CUTTER
}

\author{
K. Srinivasan, M. Venkatesh, S. Vetri Vel, S. Umapathi and M. Santhosh Kumar \\ Jayalakshmi Institute of Technology, Dharmapuri, Tamil Nadu, India
}

\begin{abstract}
Our project work is DESIGN AND FABRICATION OF NON DUST PAPER WOOD CUTTER can be used for cutting the wood by using the chart paper. Generally the paper has less stiffness, which attaches with high speed motor, the stiffness will be increased, and the respective action will be useful for cut wood pieces, lore amount of heat producing on the edge of the paper when cutting the wood pieces.

We have seen hacksaw, chisels, metal cutter, for cutting the wood on that we have different cutter used for cutting, for cutting of maximum thickness $35 \mathrm{~mm}$. we use chart paper as a cutter of various thickness for cutting the wood. And we have an analysis for cutting the wood different thickness by increasing the thickness.
\end{abstract}

Cite this Article: K. Srinivasan, M. Venkatesh, S. Vetri Vel, S. Umapathi and M. Santhosh Kumar, Design and Fabrication of Non Dust Paper Wood Cutter. International Journal of Design and Manufacturing Technology 7(1), 2016, pp. 37-49.

https://iaeme.com/Home/issue/IJDMT?Volume=7\&Issue $=1$

\section{INTRODUCTION}

Generally the paper has less stiffness, which attaches with high speed motor, the stiffness will be increased, and the respective action will be useful for cut wood pieces, lore amount of heat producing on the edge of the paper when cutting the wood pieces.

We have seen hacksaw, chisels, metal cutter, for cutting the wood on that we have different cutter used for cutting, for cutting of maximum thickness $35 \mathrm{~mm}$. we use chart paper as a cutter of various thickness for cutting the wood. And we have an analysis for cutting the wood different thickness by increasing the thickness.

\section{LITERATURE REVIEW}

\subsection{MOTOR}

In 1882, nikolatestla identified the rotating magnetic field principle, and pioneered the use of rotary field of operate machines. He exploited the principle to design a unique 
two-phase induction motor in 1885; Galileo Ferraris independently researched the concept. In 1883, Ferraris published his research in a paper to the royal academy of sciences in Turin.

\subsection{SINGLE-PHASE AC MOTOR}

Common single- phase AC motor is the split-phase induction motor, commonly used in major applications such as washing machines and clothes dryers. Compared to the shaded pole motor, these motors can generally provide much greater starting torque by using a special startup winding in conjunction with a centrifugal switch.

The phase of the magnetic field in this startup winding is shifting from the phase of the mains power, allowing the creation of a moving magnetic field which starts the motor. Once the reaches near design operating speed, centrifugal switch activates, opening the contacts and disconnecting the winding from the power source. The motor then operates solely on the ling winging. The winding must be disconnected since it would increase the losses in the motor.

\subsection{PAPER}

Paper is a commonly of thin materials produced by the amalgamation of fibers, typically vegetable fibers composed of cellulose which are subsequently held together by hydrogen bonding imparting desirable physical properties. The most common source of these kinds of fibers is wood pulp from pulpwood trees, largely softwoods and hardwoods, such as spruce and aspen respectively. Other vegetable fiber material including those of cotton, hemp linen, and rice may be used.

\subsection{PAPERMAKING}

The word paper comes from the Greek term for the ancient Egyptian writing material called papyrus, which was formed from beaten strips of papyrus plants. Papyrus was produced as early as 3000BG in Egypt, and sold to ancient Greece and Rome. Result, according to the roman historian Pliny (natural history records xiii. 21), parchment was invented under the patronage of Eugene's of Pergamum to build his rival library at Pergamum. Outside of Egypt, parchment or vellum, made of processed sheepskin or calfskin, replaced papyrus as the papyrus plant requires subtropical conditions to grow.

\subsection{WOOD}

Wood or plant cell walls are composed of fibers bound together, during pulping, these fibers are separated from each and carbohydrate surfaces, primarily cellulose or hemicellulose, are exposed. Hydrogen bonding between these carbohydrate surfaces gives papers its strength. Fibers can be separated chemically, or via a combination of the two.

\section{CONSTRUCTION AND WORKING PRINCIPLE 3.1. CONSTRUCTION}

Motor is fixed on the base board by using temporary fasteners, circular chart paper fitted at end of shaft by using spanners. The base board is fixed on the frame on certain height. 


\subsection{WORKING PRINCIPLE}

Generally the paper has less stiffness, to use paper as a cutter we should increase its stiffness, for that we attached the paper with high speed motor, the stiffness will be increased the respective action will be useful for wood pieces.

More amount of heat producing on the paper when cutting the wood pieces. We see that when the stiffness of the paper is increased then the stiffness of the paper is also increased, which is used to cut more of wood pieces.

\section{COMPONENTS USED IN PAPER WOOD CUTTER}

\subsection{Motor}

We use single phase AC series motor use for cutting the wood, the speed of the motor is 3000/min and power obtained is 1200 watts. A series A.C motor is same electrically as D.C series motor. Refer to figure and use the left hand rule for the polarity of the coils. You can that the instantaneous magnetic polarities of the armature and field oppose each other and motor action results.

Now, reverse the current by reversing the polarity of the input, note it the field polarity still opposes the armature polarity. This is because the reversal affects both the armature and the field, the A.C input causes these reversals to make place continuously. The construction of the A.C series motor differs slightly from the D.C series motor.

The special materials, laminations, and windings are used. The reduce losses caused by eddy currents, hysteretic, and high reactance D.C power can be used to drive an A.C series motor efficiency but opposite is not true. The characteristics of the A.C motor are similar to D.C motor. It is varying speed machines. It has low speed for larger loads and high speed for lighter loads.

\subsection{PAPER}

Paper is a commonly of thin materials produced by the amalgamation of fibers, typically vegetable fibers composed of cellulose which are subsequently held together by hydrogen bonding imparting desirable physical properties.

\section{MOTOR SPECIFICATION}

TABLE 5.1 Motor Specification

\begin{tabular}{|c|l|c|}
\hline SI.NO & \multicolumn{1}{|c|}{ SPECIFICATION } & UNITS \\
\hline 1 & VOLTAGE & $230 \mathrm{VOLT}$ \\
\hline 2 & FREQUENCY & $50 / 60 \mathrm{HZ}$ \\
\hline 3 & SPEED & $12000 \mathrm{R} / \mathrm{MIN}$ \\
\hline 4 & POWER & $1050 \mathrm{WATTES}$ \\
\hline 5 & PHASE & 1 AC SUPPLY \\
\hline 6 & MOTOR TYPE & SERIES-MOTOR \\
\hline 7 & MAXIMUM CUTTER DIAMETER & $110 \mathrm{MM}$ \\
\hline
\end{tabular}




\section{PERFORMANCES}

\subsection{PERFORMANCES DETAILS}

\subsubsection{TABLE-1}

WOOD THICKNESS: 2MM

CUTTI NG THICKNESS: 1MM

TABLE 6.1.1

\begin{tabular}{|c|c|c|c|c|}
\hline SI.NO. & $\begin{array}{c}\text { INITIAL } \\
\text { DIAMETER } \\
\text { OF CUTTING }\end{array}$ & $\begin{array}{c}\text { THICKNESS } \\
\text { OF } \\
\text { WORK } \\
\text { PIECES }\end{array}$ & $\begin{array}{c}\text { NUMBERS } \\
\text { OF } \\
\text { PIECES CUT }\end{array}$ & $\begin{array}{c}\text { FINAL DIAMETER } \\
\text { OF } \\
\text { CUTTING }\end{array}$ \\
\hline 1 & $100 \mathrm{~mm}$ & $2 \times 25 \mathrm{~mm}$ & 10 & $96 \mathrm{~mm}$ \\
\hline 2 & $100 \mathrm{~mm}$ & $2 \times 25 \mathrm{~mm}$ & 20 & $90 \mathrm{~mm}$ \\
\hline 3 & $100 \mathrm{~mm}$ & $2 \times 25 \mathrm{~mm}$ & 30 & $84 \mathrm{~mm}$ \\
\hline 4 & $100 \mathrm{MM}$ & $2 \times 25 \mathrm{MM}$ & 40 & $76 \mathrm{MM}$ \\
\hline
\end{tabular}

GRAFH

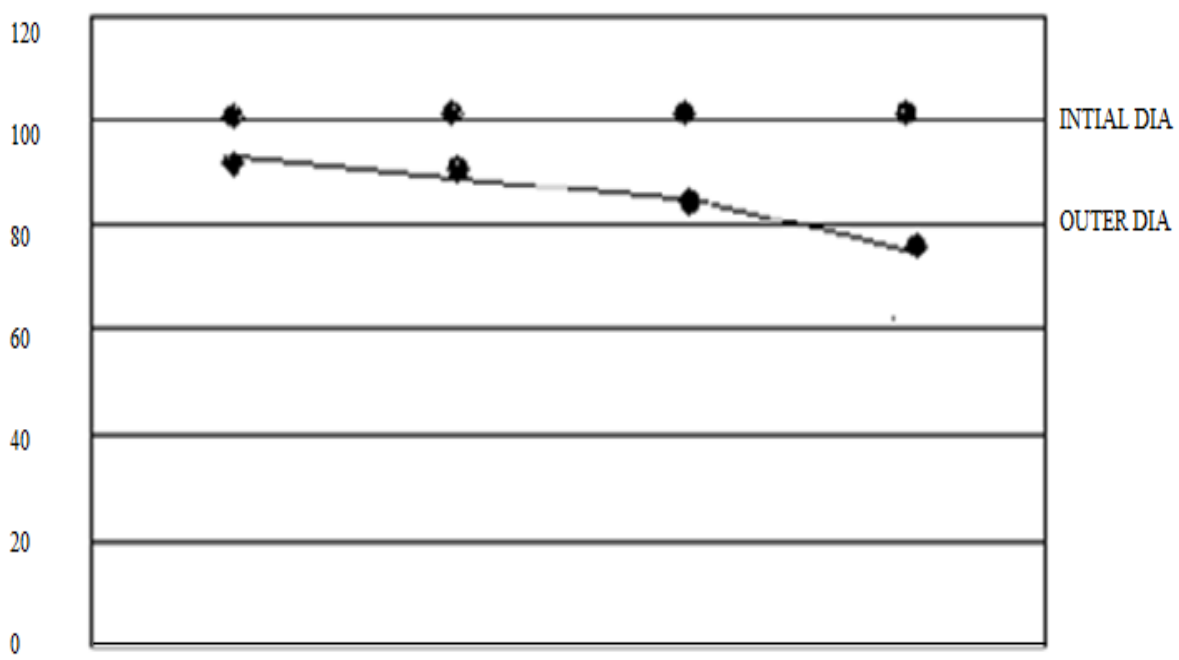

\subsubsection{TABLE-2}

WOOD THICKNESS: 3MM

CUTTING THICKNESS: 1MM

TABLE 6.1.2

\begin{tabular}{|c|c|c|c|c|}
\hline SI.NO. & $\begin{array}{c}\text { INITIAL } \\
\text { DIAMETER } \\
\text { OF CUTTING }\end{array}$ & $\begin{array}{c}\text { THICKNESS } \\
\text { OF } \\
\text { WORK } \\
\text { PIECES }\end{array}$ & $\begin{array}{c}\text { NUMBERS } \\
\text { OF } \\
\text { PIECES CUT }\end{array}$ & $\begin{array}{c}\text { FINAL DIAMETER } \\
\text { OF } \\
\text { CUTTING }\end{array}$ \\
\hline 1 & $100 \mathrm{~mm}$ & $3 \times 25 \mathrm{~mm}$ & 10 & $95 \mathrm{~mm}$ \\
\hline 2 & $100 \mathrm{~mm}$ & $3 \times 25 \mathrm{~mm}$ & 20 & $88 \mathrm{~mm}$ \\
\hline 3 & $100 \mathrm{~mm}$ & $3 \times 25 \mathrm{~mm}$ & 30 & $78 \mathrm{~mm}$ \\
\hline 4 & $100 \mathrm{~mm}$ & $3 \times 25 \mathrm{~mm}$ & 40 & $64 \mathrm{~mm}$ \\
\hline
\end{tabular}




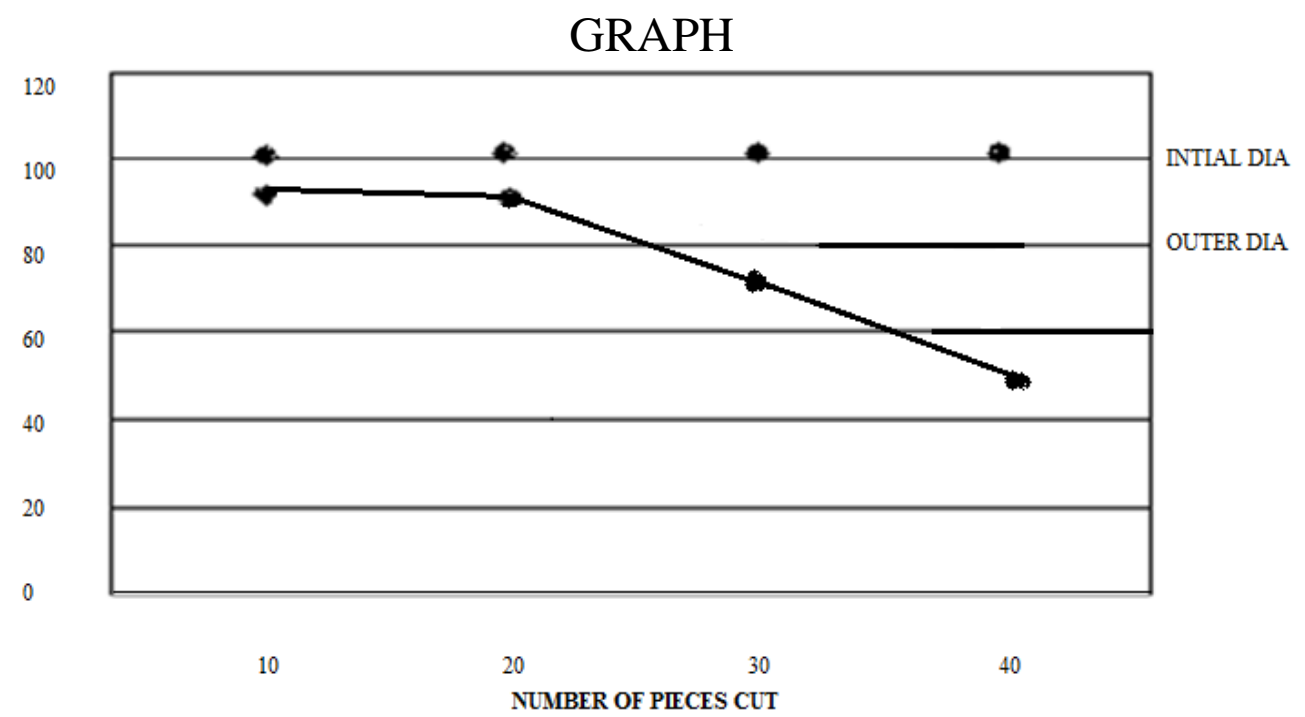

6.1.3 TABLE-3

WOOD THICKNESS: 4MM

CUTTING THICKNESS: 1MM

TABLE 6.1 .3

\begin{tabular}{|c|c|c|c|c|}
\hline SI.NO. & $\begin{array}{c}\text { INITIAL } \\
\text { DIAMETER } \\
\text { OF CUTTING }\end{array}$ & $\begin{array}{c}\text { THICKNESS } \\
\text { OF } \\
\text { WORK } \\
\text { PIECES }\end{array}$ & $\begin{array}{c}\text { NUMBERS } \\
\text { OF } \\
\text { PIECES CUT }\end{array}$ & $\begin{array}{c}\text { FINAL DIAMETER } \\
\text { OF } \\
\text { CUTTING }\end{array}$ \\
\hline 1 & $100 \mathrm{~mm}$ & $4 \times 25 \mathrm{~mm}$ & 10 & $94 \mathrm{~mm}$ \\
\hline 2 & $100 \mathrm{~mm}$ & $4 \times 25 \mathrm{~mm}$ & 20 & $88 \mathrm{~mm}$ \\
\hline 3 & $100 \mathrm{~mm}$ & $4 \times 25 \mathrm{~mm}$ & 30 & $74 \mathrm{~mm}$ \\
\hline 4 & $100 \mathrm{~mm}$ & $4 \times 25 \mathrm{~mm}$ & 40 & $63 \mathrm{~mm}$ \\
\hline
\end{tabular}

GRAPH

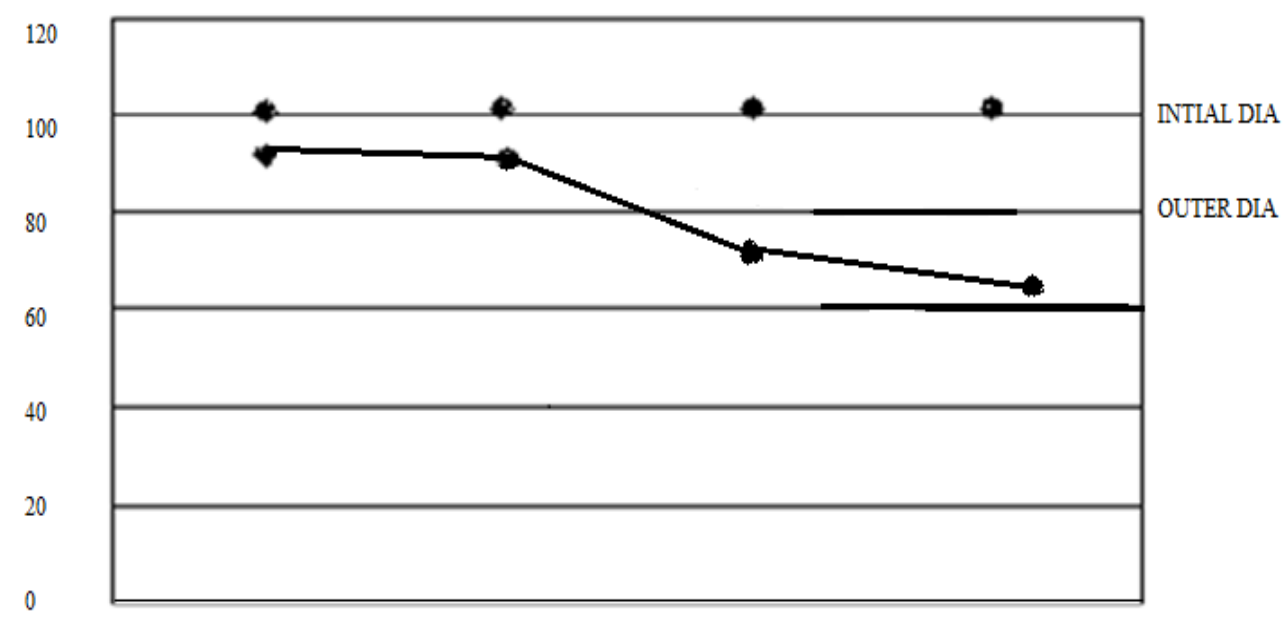

10

$20 \quad 30$

40

NUMBER OF PIECES CUT 
6.1.4 TABLE-4

WOOD THICKNESS: 5MM

CUTTING THICKNESS: 1MM

TABLE 6.1.4

\begin{tabular}{|c|c|c|c|c|}
\hline SI.NO. & $\begin{array}{c}\text { INITIAL } \\
\text { DIAMETER } \\
\text { OF CUTTING }\end{array}$ & $\begin{array}{c}\text { THICKNESS } \\
\text { OF } \\
\text { WORK } \\
\text { PIECES }\end{array}$ & $\begin{array}{c}\text { NUMBERS } \\
\text { OF } \\
\text { PIECES CUT }\end{array}$ & $\begin{array}{c}\text { FINAL DIAMETER } \\
\text { OF } \\
\text { CUTTING }\end{array}$ \\
\hline 1 & $100 \mathrm{~mm}$ & $5 \times 25 \mathrm{~mm}$ & 5 & $83 \mathrm{~mm}$ \\
\hline 2 & $100 \mathrm{~mm}$ & $5 \times 25 \mathrm{~mm}$ & 7 & $76 \mathrm{~mm}$ \\
\hline 3 & $100 \mathrm{~mm}$ & $5 \times 25 \mathrm{~mm}$ & 10 & $65 \mathrm{~mm}$ \\
\hline
\end{tabular}

GRAPH

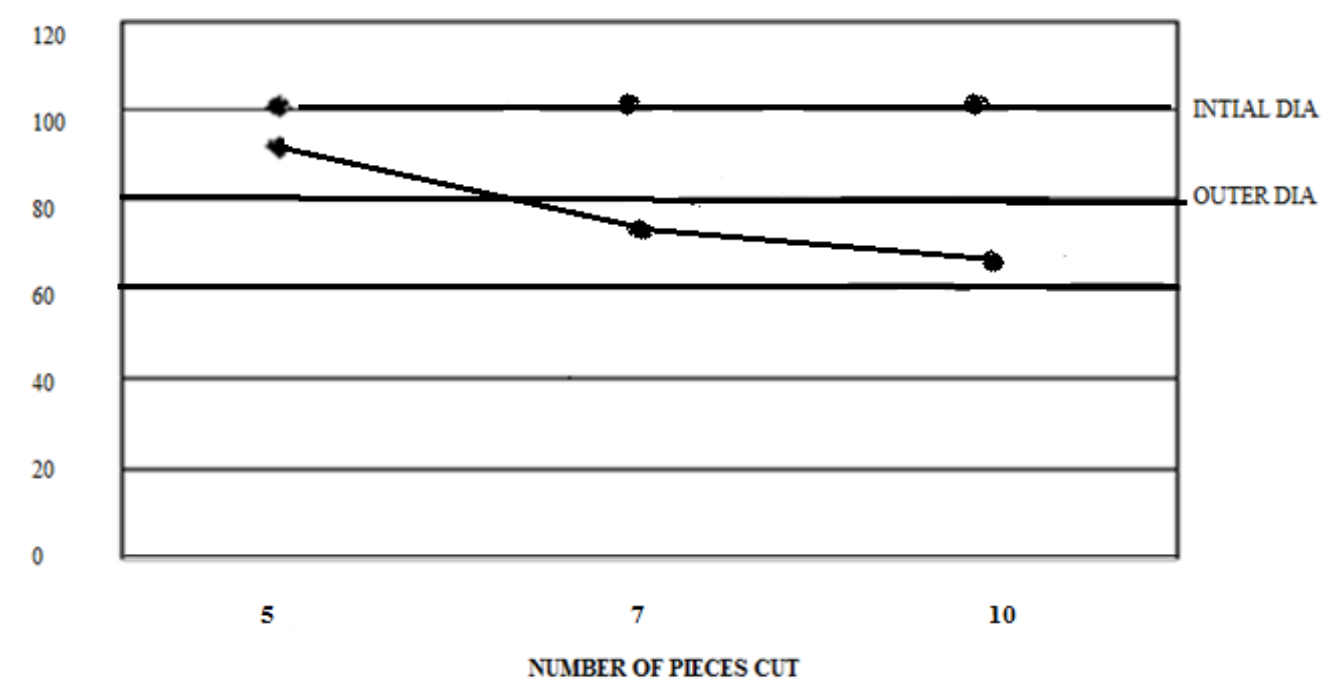

6.1.5 TABLE-5

WOOD THICKNESS: 6MM

CUTTING THICKNESS: 1MM

TABLE 6.1.5

\begin{tabular}{|c|c|c|c|c|}
\hline SI.NO. & $\begin{array}{c}\text { INITIAL } \\
\text { DIAMETER } \\
\text { OF CUTTING }\end{array}$ & $\begin{array}{c}\text { THICKNESS } \\
\text { OF } \\
\text { WORK } \\
\text { PIECES }\end{array}$ & $\begin{array}{c}\text { NUMBERS } \\
\text { OF } \\
\text { PIECES CUT }\end{array}$ & $\begin{array}{c}\text { FINAL DIAMETER } \\
\text { OF } \\
\text { CUTTING }\end{array}$ \\
\hline 1 & $100 \mathrm{~mm}$ & $6 \times 25 \mathrm{~mm}$ & 4 & $82 \mathrm{~mm}$ \\
\hline 2 & $100 \mathrm{~mm}$ & $6 \times 25 \mathrm{~mm}$ & 8 & $71 \mathrm{~mm}$ \\
\hline 3 & $100 \mathrm{~mm}$ & $6 \times 25 \mathrm{~mm}$ & 12 & $62 \mathrm{~mm}$ \\
\hline
\end{tabular}


GRAPH

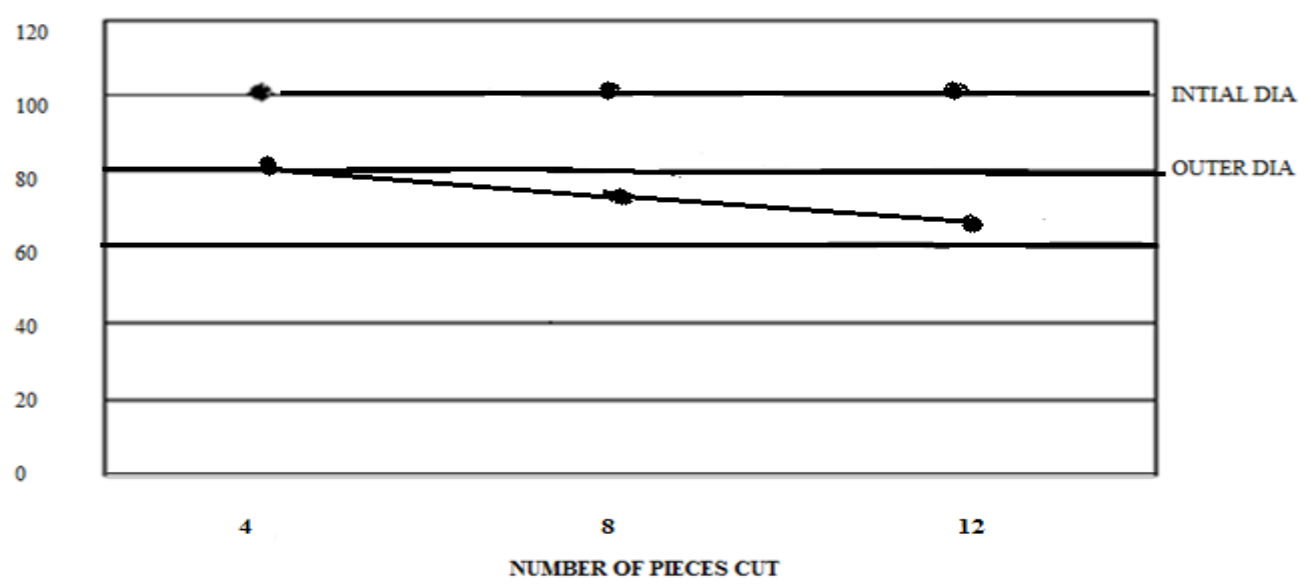

\subsubsection{TABLE-6}

WOOD THICKNESS: 7MM

CUTTING THICKNESS: 1MM

TABLE 6.1.6

\begin{tabular}{|c|c|c|c|c|}
\hline SI.NO. & $\begin{array}{c}\text { INITIAL } \\
\text { DIAMETER } \\
\text { OF CUTTING }\end{array}$ & $\begin{array}{c}\text { THICKNESS } \\
\text { OF } \\
\text { WORK } \\
\text { PIECES }\end{array}$ & $\begin{array}{c}\text { NUMBERS } \\
\text { OF } \\
\text { PIECES CUT }\end{array}$ & $\begin{array}{c}\text { FINAL DIAMETER } \\
\text { OF } \\
\text { CUTTING }\end{array}$ \\
\hline 1 & $100 \mathrm{~mm}$ & $7 \times 25 \mathrm{~mm}$ & 4 & $75 \mathrm{~mm}$ \\
\hline 2 & $100 \mathrm{~mm}$ & $7 \times 25 \mathrm{~mm}$ & 7 & $60 \mathrm{~mm}$ \\
\hline 3 & $100 \mathrm{~mm}$ & $7 \times 25 \mathrm{~mm}$ & 12 & $49 \mathrm{~mm}$ \\
\hline
\end{tabular}

GRAPH

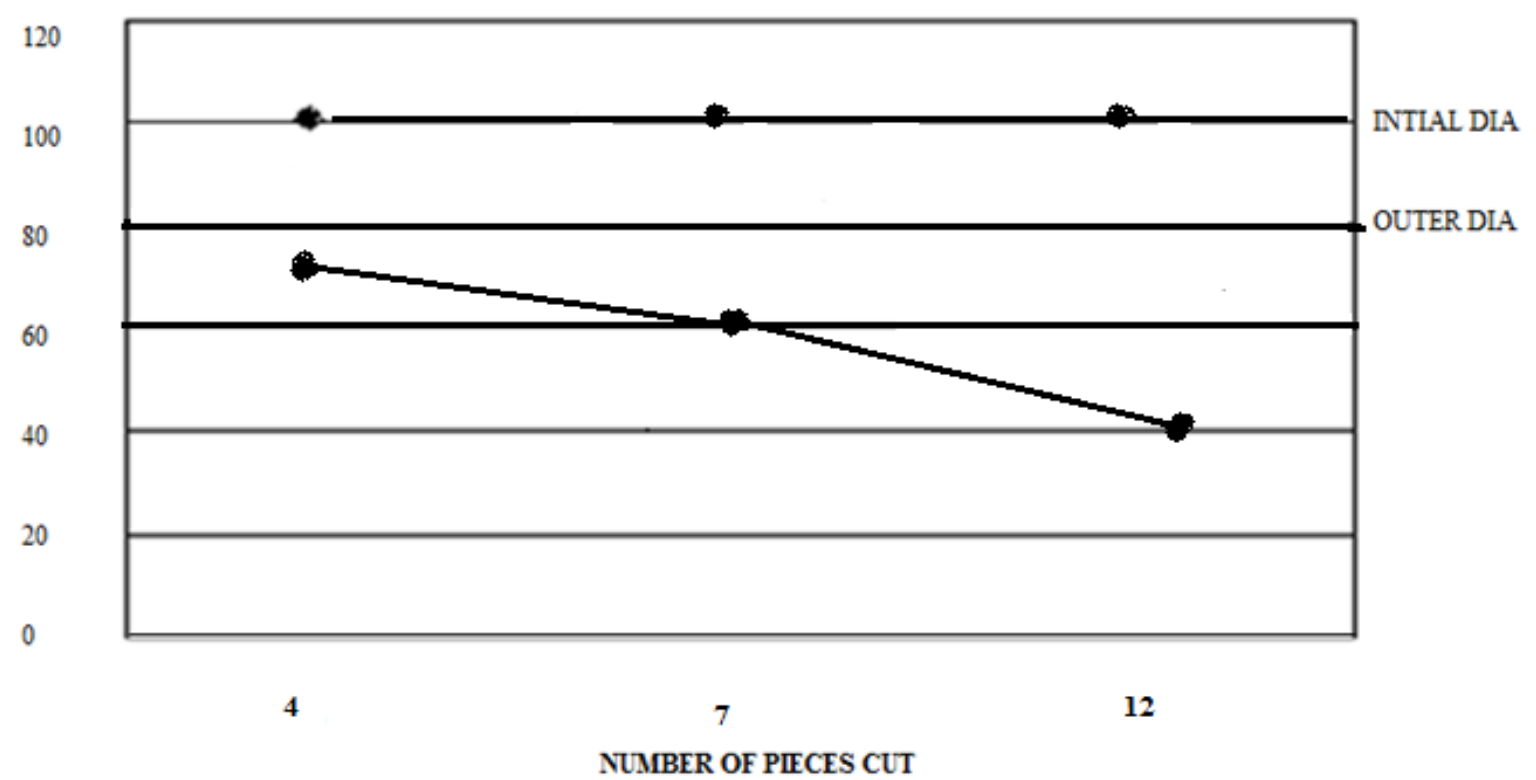




\subsubsection{TABLE-7}

WOOD THICKNESS: 8MM

CUTTING THICKNESS: 1MM

TABLE 6.1.7

\begin{tabular}{|c|c|c|c|c|}
\hline SI.NO. & $\begin{array}{c}\text { INITIAL } \\
\text { DIAMETER } \\
\text { OF CUTTING }\end{array}$ & $\begin{array}{c}\text { THICKNESS } \\
\text { OF } \\
\text { WORK } \\
\text { PIECES }\end{array}$ & $\begin{array}{c}\text { NUMBERS } \\
\text { OF } \\
\text { PIECES CUT }\end{array}$ & $\begin{array}{c}\text { FINAL DIAMETER } \\
\text { OF } \\
\text { CUTTING }\end{array}$ \\
\hline 1 & $100 \mathrm{~mm}$ & $8 \times 25 \mathrm{~mm}$ & 3 & $74 \mathrm{~mm}$ \\
\hline 2 & $100 \mathrm{~mm}$ & $8 \times 25 \mathrm{~mm}$ & 7 & $58 \mathrm{~mm}$ \\
\hline 3 & $100 \mathrm{~mm}$ & $8 \times 25 \mathrm{~mm}$ & 10 & $49 \mathrm{~mm}$ \\
\hline
\end{tabular}

GRAPH

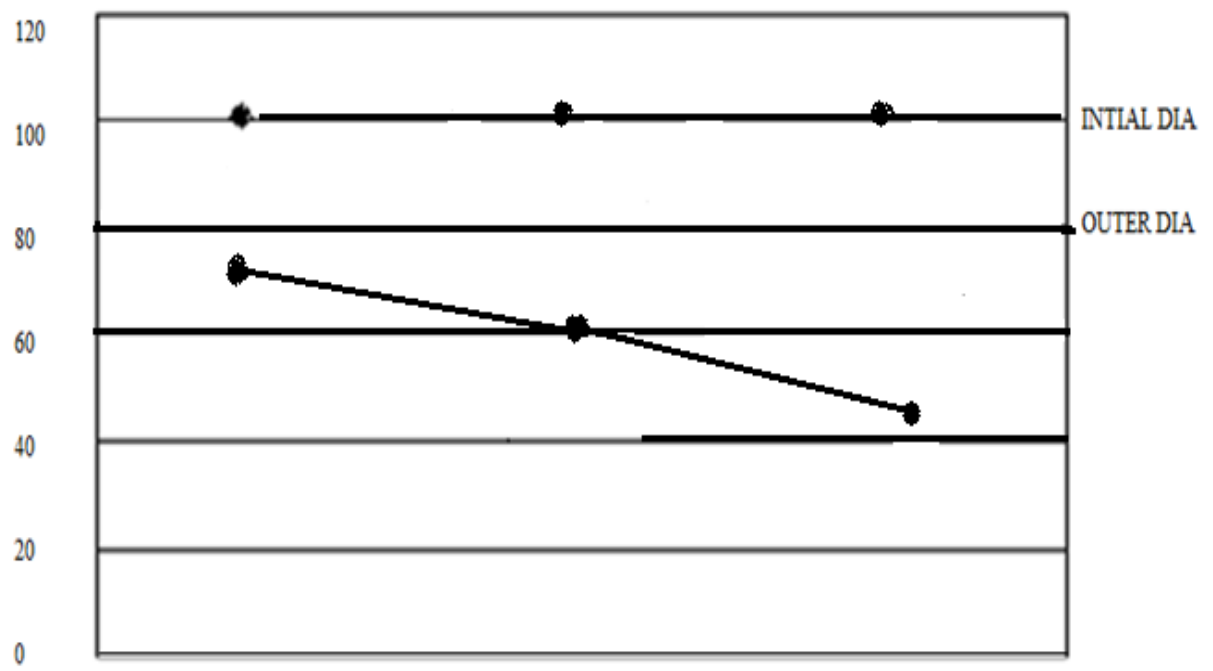

3

7

10

NTMBER OF PIECES CUT

6.1.8 TABLE-8

WOOD THICKNESS: 9MM

CUTTING THICKNESS: 1MM

TABLE 6.1.8

\begin{tabular}{|c|c|c|c|c|}
\hline SI.NO. & $\begin{array}{c}\text { INITIAL } \\
\text { DIAMETER } \\
\text { OF CUTTING }\end{array}$ & $\begin{array}{c}\text { THICKNESS } \\
\text { OF } \\
\text { WORK } \\
\text { PIECES }\end{array}$ & $\begin{array}{c}\text { NUMBERS } \\
\text { OF } \\
\text { PIECES CUT }\end{array}$ & $\begin{array}{c}\text { FINAL DIAMETER } \\
\text { OF } \\
\text { CUTTING }\end{array}$ \\
\hline 1 & $100 \mathrm{~mm}$ & $9 \times 25 \mathrm{~mm}$ & 2 & $65 \mathrm{~mm}$ \\
\hline 2 & $100 \mathrm{~mm}$ & $9 \times 25 \mathrm{~mm}$ & 4 & $48 \mathrm{~mm}$ \\
\hline 3 & $100 \mathrm{~mm}$ & $9 \times 25 \mathrm{~mm}$ & 6 & $39 \mathrm{~mm}$ \\
\hline
\end{tabular}




\section{GRAPH}

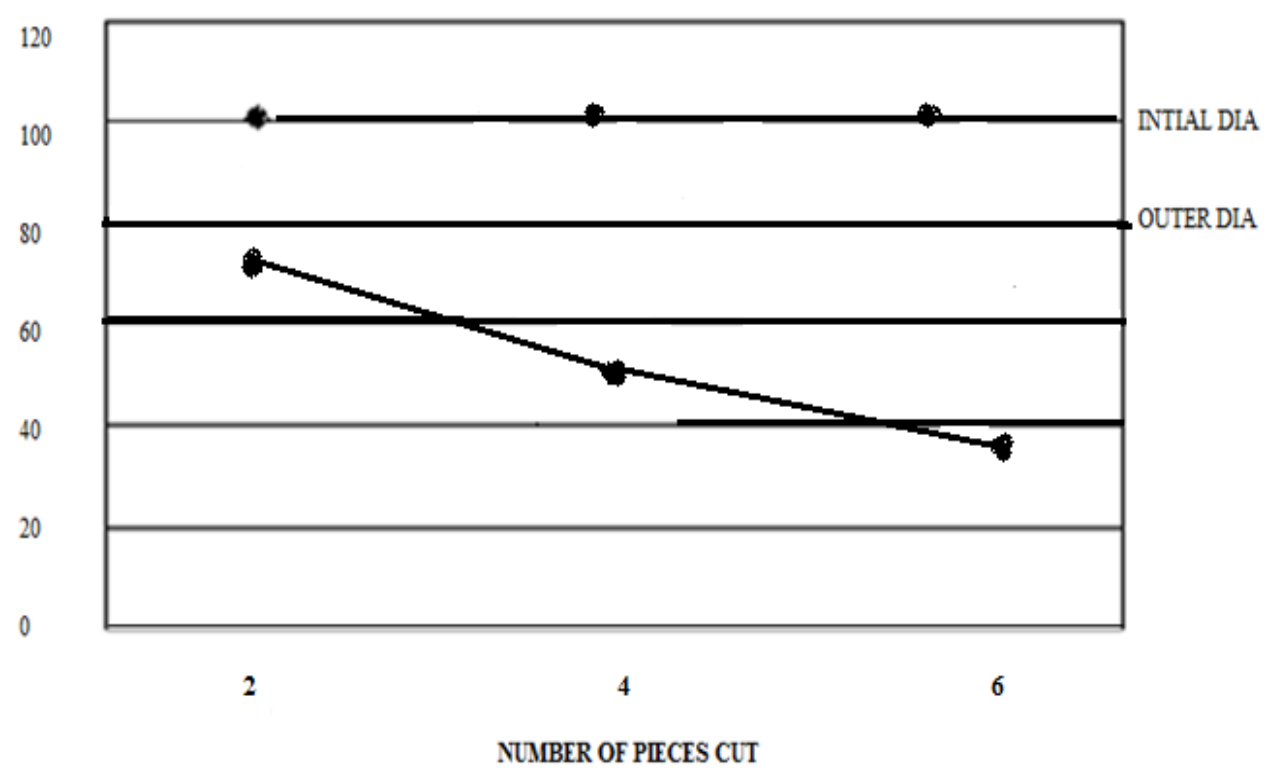

\subsubsection{TABLE-9}

WOOD THICKNESS: 10MM

CUTTING THICKNESS: 1MM

Table 6.1.9

\begin{tabular}{|c|c|c|c|c|}
\hline SI.NO. & $\begin{array}{c}\text { INITIAL } \\
\text { DIAMETER } \\
\text { OF CUTTING }\end{array}$ & $\begin{array}{c}\text { THICKNESS } \\
\text { OF } \\
\text { WORK } \\
\text { PIECES }\end{array}$ & $\begin{array}{c}\text { NUMBERS } \\
\text { OF } \\
\text { PIECES CUT }\end{array}$ & $\begin{array}{c}\text { FINAL DIAMETER } \\
\text { OF } \\
\text { CUTTING }\end{array}$ \\
\hline 1 & $100 \mathrm{~mm}$ & $10 \times 25 \mathrm{~mm}$ & 2 & $58 \mathrm{~mm}$ \\
\hline 2 & $100 \mathrm{~mm}$ & $10 \times 25 \mathrm{~mm}$ & 4 & $52 \mathrm{~mm}$ \\
\hline 3 & $100 \mathrm{~mm}$ & $10 \times 25 \mathrm{~mm}$ & 6 & $48 \mathrm{~mm}$ \\
\hline 4 & $100 \mathrm{~mm}$ & $10 \times 25 \mathrm{~mm}$ & 4 & $33 \mathrm{~mm}$ \\
\hline
\end{tabular}

\section{GRAPH}

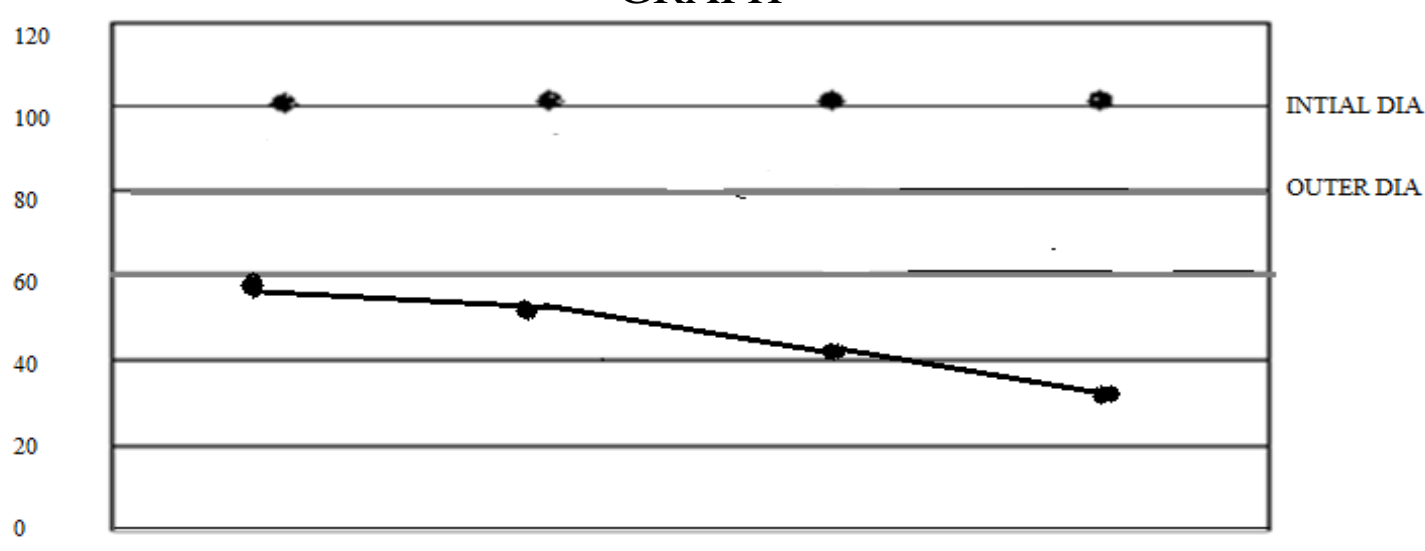




\subsection{Chart Paper}

We use chart paper for cutting the wood, the stiffness of the chart paper is very less. We cut the chart paper of circular shape maximum diameter of $100 \mathrm{~mm}$. The thickness of the paper is $0.5 \mathrm{~mm}$; we increase the thickness by attaching the chart paper.

\subsection{Cutting materials}

Wood is a solid material derived from woody plants, notably trees but also shrubs. Wood from the latter is only produced in small sizes, reducing diversity of uses. In its most common meaning, "WOOD" is the secondary xylem of a woody plan, but this is an approximation only: in the wider sense, wood may refer to other materials and tissues with comparable properties. Wood is a heterogeneous, hygroscopic, cellular and anisotropic material. Wood is composed of fibers of cellulose and anisotropic materials. Wood is composed of fibers of cellulose and anisotropic material (15\%$25 \%)$ held together by lignin $(15 \%-30 \%)$

Wood has been used for millennia for many purposes. One of its primary uses is as fuel. It is also used as for making artworks, furniture tools, and weapons, and as construction materials. Wood has been an important construction materials since humans began building shelters, houses, bolts, nearly all bolts were made out of wood till the late 1800's. It remains in common use today for wooden bolts and wooden materials (notably in roof construction) or exterior decoration. Wood to be used for construction work is commonly known as lumber in North America. Elsewhere, lumber usually refer to felled trees and the word for sawn planks (etc), ready for will be timber.

Wood which in its native from is unsuitable for construction may be broken down mechanically (into fibers or chips) or chemically (into cellulose) and used as a raw material for other building material such as chipboard, engineered wood, hardboard, medium-density fiberboard (MDF), oriented board (OSB).

Also, wood fibers are important components of paper, and cellulose is used as a component of synthetic materials. It can also be used for kinds of flooring for example laminate flooring wood can also be used for cutler, such as chopsticks and toothpicks, and utensils, such has as the wooden spoon. A tree increase in diameter by the friction between the old wood and the inner bark, of new woody layers which envelop the entire stem, living branches, and roots. Where there are clear seasons, this can happen in a discrete pattern, leading pattern, leading to what is known as growth rings are annual rings. Within a growth ring it may be possible to see two parts.

The part nearest the center of the tree is more open textured and almost invariably lighter in color than that near the outer portion textured and portion is formed early in the season, when growth is comparatively repaid; is wood, as early wood or spring wood. The outer portion is the late wood or summer wood, being produced in the summer. In white pines there is not much contrast in the different parts of the ring, and as a result the wood is very uniform in texture and is easy to work. In hard pines, on the other hand, the late wood is very dense and is deep-colored, presenting a very decided contrast to the soft, straw-colored early wood. In ring-porous woods each season's growth is always well defined, because the large pores of the spring about on the denser tissue of the fall before. In the diffuse-porous woods, the demarcation between rings is not always so clean and in some cases is almost (if not entirely) invisible to the unaided eye. 


\section{DIAGRAM}

\subsection{MOTOR DIAGRAM}

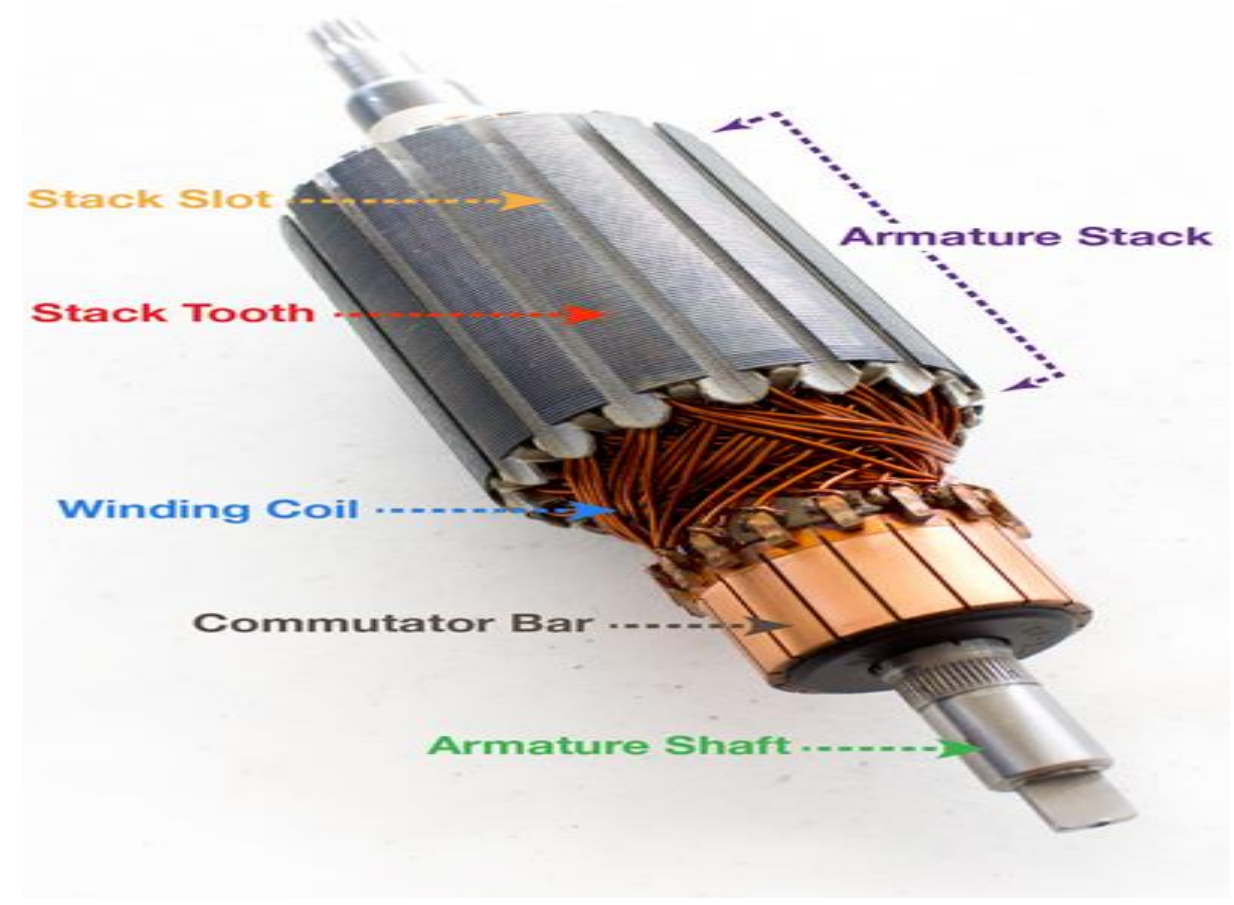

Figure 7.1 Motor diagrams

\subsection{MACHINE DIAGRAM}

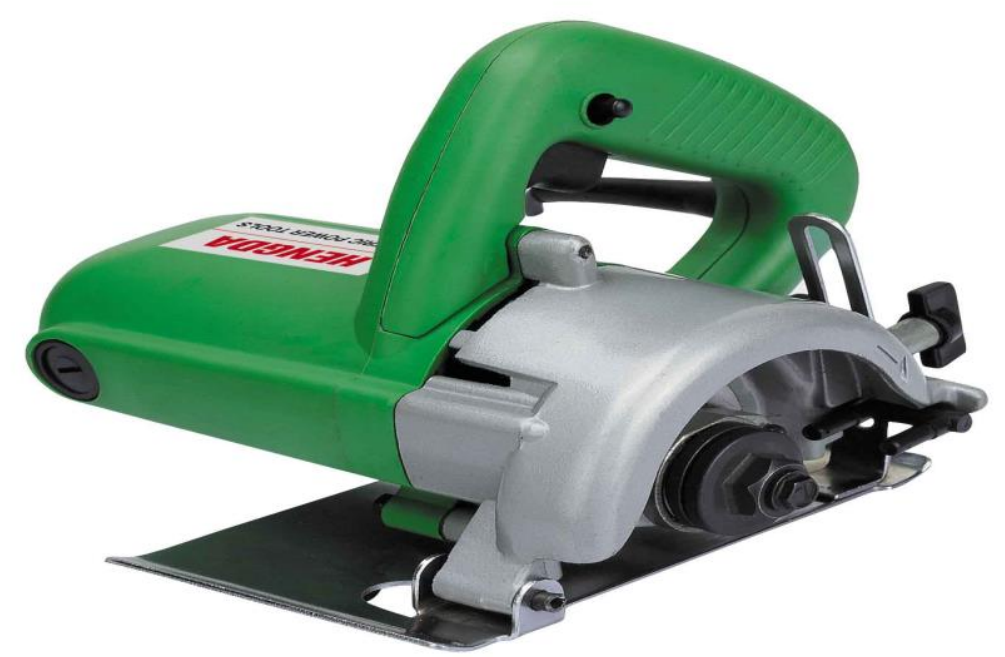

Figure 7.2 Machine Diagram 


\subsection{DIAGRAM OF WOOD PIECE}

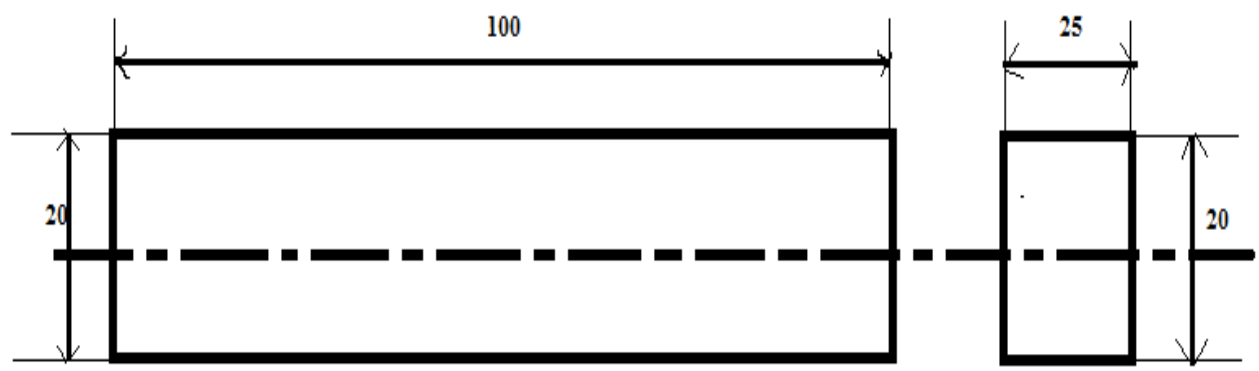

LENGTH $=100$

THICKNESS $=20$

WIDTH $=25$

Figure 7.3 Wood piece

\subsection{CUTTER DIAGRAM}

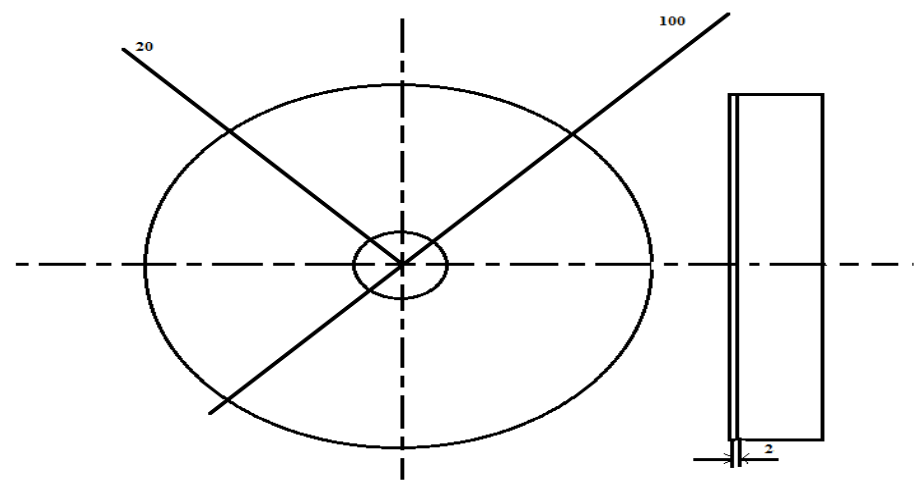

THICKNESS $=0.2$

OUTER DIA $=100$

INNER DIA $=20$

Figure 7.4 Cutter Diagram

\section{MODIFICATIONS}

- In this project, we paper as a cutter instead of using hacksaw, chisels, etc.

- Cost is reduced because of using paper as cutter.

- We can increase the thickness of the paper cutter, so that the cutter efficiency is increased.

- If we increase the cutter diameter, paper cutter will be flexible and cutter will wear out easily.

- So the suitable diameter must be used. 


\section{ADVANDAGES}

- Cutter cost low.

- Compact size.

- Easy to handle.

- Easy to maintain.

- Finishing is good.

\section{APPLICATION}

- It is used to cut woods up to $3.5 \mathrm{~cm}$.

- It is mainly used to cut photo frames.

- It should be used to industrial purpose.

- It is uses to home applications.

\section{CONCLUSION}

Our project is "DESIGN AND FABRICATION OF NON DUST PAPER WOOD CUTTER" can be used for cutting the wood by using the chart paper. For future work instead of using paper we can use fiber sheet, mica sheet. During the course of action of our work, we have gained sufficient technical as well as practical knowledge as how a machine is to be designed, fabrication, and priced. This machine was fabricated successfully and tested. It works properly. We hope that this will be one among the most versatile and interchangeable one even if future.

\section{REFERANCES}

[1] Donald G. fink and H. Wayne Beaty, standard hand book for electrical engineers, eleventh edition, McGraw-Hill, (1978), New York, ISBN 07020974-x.

[2] Edwin J.Houston and Arthur Kennelly, recent types of dynamo-electric machinery, copyright American technical book company 1897, published by P.F collier and sons New York, 1902.

[3] Kuphaldt, tony R. (2000)-(2006). "Chapter 13 AC MOTORS", lessons in electric circuits-volume ii. Retrieved on 2006 April 11. A.O. Smith: the AC's and DC's of electrical motors. Retrieved on 2006-04-11.

[4] J. Rosenblatt \& M. H. Friedman "Direct and Alternating Current Machinery" 2nd Ed. Merrill, Colombus Ohio 1984.

[5] U.S department of Agriculture, forest products laboratory. The wood handbook: wood as an engineering material. General technical report 113. Madison, WI.

[6] David Goodman and Arash Edalatnoor, Waste Just another Resource: A Case for Waste Wood. International Journal of Mechanical Engineering\& Technology 6(3), 2015, pp. 25-33.

[7] Hoadley, R. Bruce. (2000) understanding wood: a craftsman's guide to wood technology. Taunton press. ISBN 1-56158-358-8 